\title{
Frontal auxiliary impressions in the Ordovician trilobite Dalmanitina Reed, 1905 from the Barrandian area, Czech Republic
}

\author{
OldŘIICH FATKA \& Petr BudIL
}

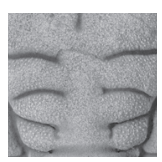

\begin{abstract}
Fossils preserved in Cambrian to Devonian sediments of the Barrandian area (Czech Republic) have contributed significantly to our knowledge of numerous invertebrate groups. With respect to trilobites, important data has been discovered on the construction of eyes, healing of exoskeletal injuries, as well as on the morphology of soft parts. The generally rarely preserved frontal auxiliary impressions (FAIs) on the glabellar surface of trilobites were first described in Devonian examples from this area in the mid-nineteenth century by Barrande. Such impressions have only rarely been documented in a few trilobite species in the Lower Palaeozoic of the Barrandian area. Here we describe twelve exceptionally preserved holaspid cephalic shields of Dalmanitina socialis Barrande, 1846. These specimens are internal moulds and were collected at three localities in the Upper Ordovician Letná Formation. This material documents a high level of variability in the disposition of FAIs within the glabella. However, the FAIs show a common pattern at the anterior glabellar margin and are arranged in two pairs around a medial impression and are also associated with a third pair situated more posterolaterally. This current study is the first to focus on the distribution of FAIs within the Dalmanitidae. Dalmanitina socialis specimens with FAIs from the Letná Formation indicate that the depositional environment at the several localities in that unit was favourable to exceptional preservation. Excellently preserved cephalic shields of Dalmanitina demonstrate the presence of the posterior median impression (pmi) of Eldredge (1972) and enable new terminology to be proposed for other FAIs. • Key words: Trilobites, frontal auxiliary impressions, soft-tissue preservation, Letná Formation, Upper Ordovician, Czech Republic.
\end{abstract}

Fatka, O. \& Budil, P. 2021. Frontal auxiliary impressions in the Ordovician trilobite Dalmanitina Reed, 1905 from the Barrandian area, Czech Republic. Bulletin of Geosciences 96(4), 481-491 (6 figures). Czech Geological Survey, Prague. ISSN 1214-1119. Manuscript received July 10, 2020; accepted in revised form August 11, 2021; published online August 29, 2021; issued October 1, 2021.

Oldrich Fatka, Charles University, Institute of Geology and Palaeontology, Albertov 6, 12843 Prague 2, Czech Republic; fatka@natur.cuni.cz • Petr Budil, Czech Geological Survey, Klárov 3, 11821 Prague 1, Czech Republic

Trilobites from the Cambrian to Devonian sediments of the Barrandian area (Czech Republic) have contributed significantly to our knowledge of their palaeobiology, such as the construction of their eyes, the nature of their exoskeletal injuries and their soft-part morphology, for instance their digestive system (see e.g. Budil \& Fatka 2020). With respect to auxiliary glabellar impressions, it was Barrande (1852, pp. 111, 112) who first noticed and figured in several trilobites the presence of these, and twenty years later he $(1872$, pp. 150,151$)$ described the occurrence of 'impressions auxiliaires' in greater detail. In the present contribution, we describe twelve exceptionally preserved late holaspid cephalic shields of the abundant species Dalmanitina socialis (Barrande, 1846), all collected from three localities in the lower Sandbian Letná Formation. This study represents the first detailed analysis of frontal auxiliary impressions (FAIs) in the Dalmanitidae.

\section{Geological setting}

Havlíček \& Vaněk (1966) compiled a comprehensive list of species from the Ordovician of the Prague Basin, including taxa from the Letná Formation. Earlier data on the geological setting, skeletal fossils and faunal assemblages of the Letná Formation has been recently summarized by Fatka et al. (2013) and Drage et al. (2018). At several outcrops containing the Dalmanitina-Deanaspis Association of Havlíček \& Vaněk (1990), rare remains of non-mineralized to slightly mineralized fossils have been discovered, including rare trilobites with the remains of their alimentary tract (Jahn 1893; Chlupáč 1988, 1999a, b; Rak et al. 2013; Fatka et al. 2013).

Dalmanitina Reed, 1905 in the Prague Basin. - In the Prague Basin, Dalmanitina is found exclusively in sedi- 

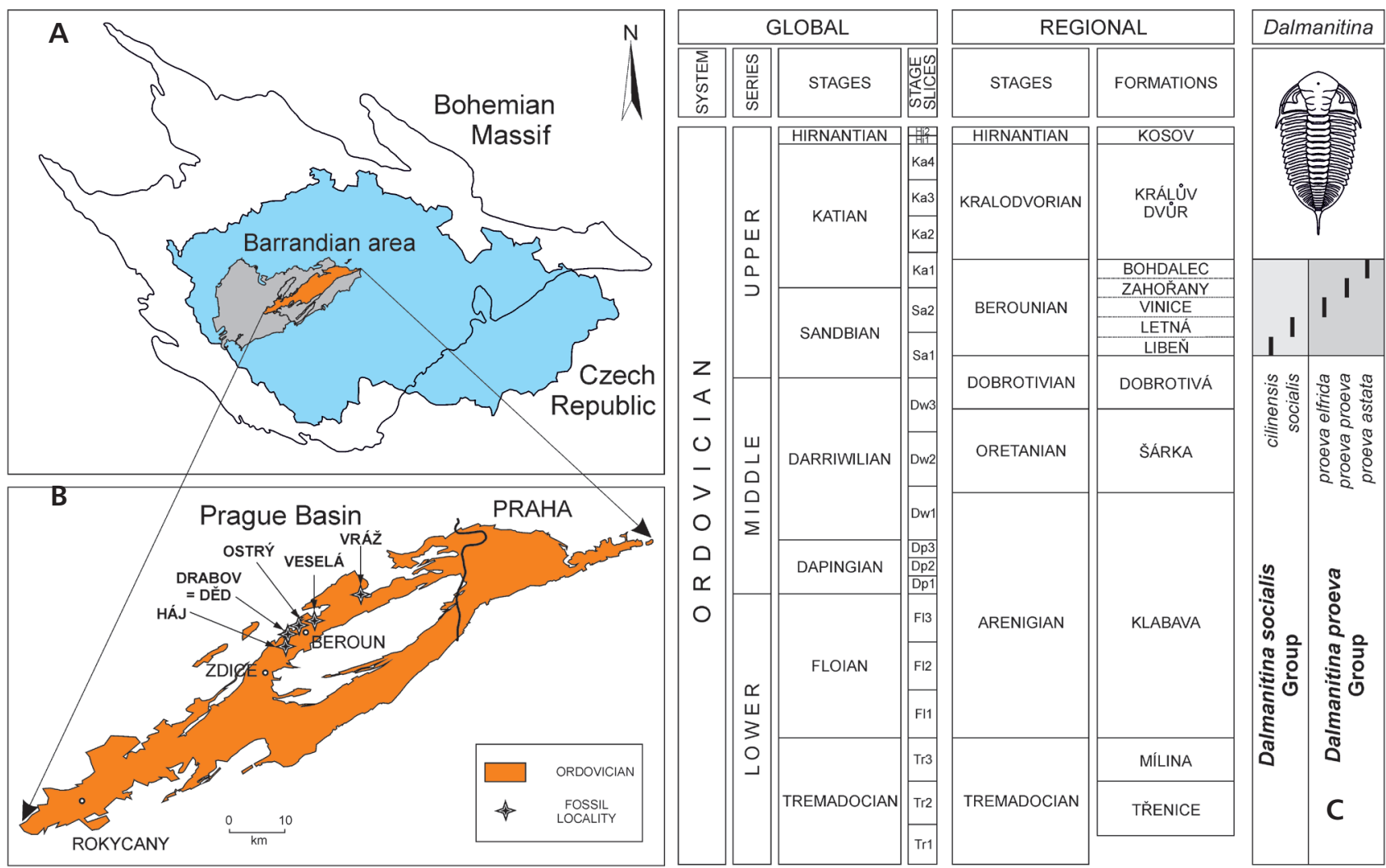

Figure 1. A - sketch map of the Czech Republic and the Barrandian area. $・ \mathrm{~B}$ - sketch map of the Prague Basin showing the location of Drabov Hill (= Děd), Beroun; Veselá Hill, Beroun; Ostrý Hill and Háj near Zahořany, at which the trilobites with FAIs studied herein were found. $\bullet$ - stratigraphy of the Ordovician of the Prague Basin, with levels at which specimens of Dalmanitina socialis (Barrande, 1846) with FAIs were collected (stratigraphy modified from Budil et al. 2011).

ments of the Berounian Regional Stage (Fig. 1C), which corresponds to the Sandbian to lower to middle Katian of the international stratigraphic standard (see Havlíček \& Marek 1973, Bergström et al. 2009, Fatka et al. 2013). The systematics of Dalmanitina in Bohemia has been studied especially by Šnajdr (1956, 1982a, b, 1987, 1990) and more recently also by Vaněk \& Vokáč (1997). Two informal groups can be distinguished within Dalmanitina in the Barrandian area, the Dalmanitina socialis group [this includes D. socialis (Barrande, 1846) and D. cilinensis Šnajdr, 1956] and the D. proaeva group [this includes D. proaeva proaeva (Emmrich, 1839), D. proaeva elfrida Šnajdr, 1982a and D. proeva asta Šnajdr, 1982a] (see also Drage et al. 2018).

\section{Material and methods}

The specimens used in this study are all internal moulds and they belong to three historical collections: that of Joachim Barrande in the National Museum, Prague (NM L 59867, 59868), that of the Czech Geological Survey, Prague (ČGS MŠ 7212, 7229, 1237, 7244, 7253, 7255 and
XA 023a-b) and that of the Museum für Naturkunde, Berlin (MFN T 1638.1 and T 1638.3). These specimens were collected from three localities: from Veselá and Děd near Beroun, and from the Ostrý hills (Fig. 1B). All specimens are preserved as internal moulds in light to dark yellow or pale brown quartzose sandstone (Figs $3-5)$. They are more than $32 \mathrm{~mm}$ in sagittal length and correspond to a late holaspid growth stage. Only the internal moulds were studied, as the external moulds were not usually collected in the $19^{\text {th }}$ century and are mostly absent in the historical collections. Photographs were taken using a NIKON D 300 digital camera, and specimens were coated with ammonium chloride sublimate beforehand. Drawings were made from the photographs using Corel Draw X3 and Photoshop CS5.

\section{Terminology of frontal auxiliary impressions}

The morphological term 'Frontal Auxiliary Impressions' (FAIs) was proposed by Lerosey-Aubril et al. (2011, p. 167) to distinguish glabellar muscle scars located on 
the frontal glabellar lobe only. FAIs were interpreted as related to the extrinsic musculature of the foregut, distinct from the muscle scars associated with the glabellar furrows and likely representing insertion sites for the musculature of the appendages. FAIs refer to a specific subset of muscle scars borne by the glabella, whereas other terms such as 'auxiliary impressions' (= impressions auxiliaires) of Barrande (1852, 1872), Harrington (1959), Šnajdr (1990) and Budil et al. (2009, pp. 65, 67, fig. 3), 'auxiliary musculature' of Born (1919), 'auxiliary muscle impressions' of Eldredge (1972, p. 143), or 'auxiliary impression system' of Eldredge \& Braniša (1980, p. 190), Edgecombe (1993), Ramsköld \& Edgecombe (1993, p. 275), Edgecombe \& Fortey (2000, pp. 334, 337, 340) referred to all of them. Lerosey-Aubril et al. (2011) and Lerosey-Aubril \& Peel (2018, p. 748) hypothesized that all trilobites might have possessed muscles associated with the foregut, at least as suspensor muscles, but in most taxa this musculature was too delicate to leave external marks on the dorsal exoskeleton. These authors also supposed a limited use of the distribution pattern of FAIs for the study of phylogenetic relationships between major trilobite groups.

Analysis of impressions preserved in specimens of Dalmanitina socialis examined in the current study shows a common pattern in the disposition of at least eight FAIs (Fig. 2). Two more or less prominent, non-paired pits are placed medially, one situated anteriorly to S3 glabellar furrows (= pmi of Eldredge 1972, see below), the other at the anterior glabellar margin. Four other impressions are arranged in two pairs situated around the non-paired anterior median impression. The third pair of impressions is located more posterolaterally. In wellpreserved specimens, the following types of FAIs may be distinguished:

1) Posterior median impression (pmi) - is a deep elongate pit sometimes forming a sagittal groove located on the inner surface of the posterior part of the frontal glabellar lobe anterior to S3); the pmi was first used and discussed by Eldredge (1972, p. 149, text-fig. 6c) in the calmoniid Bouleia.

2) Anterior median impression (ami) - is a conspicuous, transversally elongate elliptical pit located sagitally in the preglabellar furrow. A similar impression developed as a pad and located sagittally near the anterior border furrow in Calyptaulax holstenensis was discussed and figured by Eldredge (1971, p. 58, fig. 3).

3) Anterior lateral impressions (ali) - are represented by four impressions arranged in two pairs flanking the ami laterally.

4) Abaxial impressions (abi) - are a pair of large impressions placed posteriorly from the anterolateral margin of the glabella; they are positioned abaxially opposite the mid-distance between ami and pmi. They represent the most abaxial FAIs and delimit a diamond-shaped area where most of the more minor FAIs are located.

The main abaxial rows commonly become obsolescent as they converge posteriorly at the midline.
Figure 2. Frontal auxiliary impressions on the glabella of Dalmanitina socialis. A - the general pattern of frontal auxiliary impressions (FAIs) and terminology proposed herein, the dashed boundary lines indicate the posterolateral limits of the area where FAIs occur, the dotted area covers the surface where small FAIs are commonly arranged in two oblique rows; $\mathrm{B}$ - distribution of FAIs in all herein studied specimens of Dalmanitina socialis (Barrande, 1846).

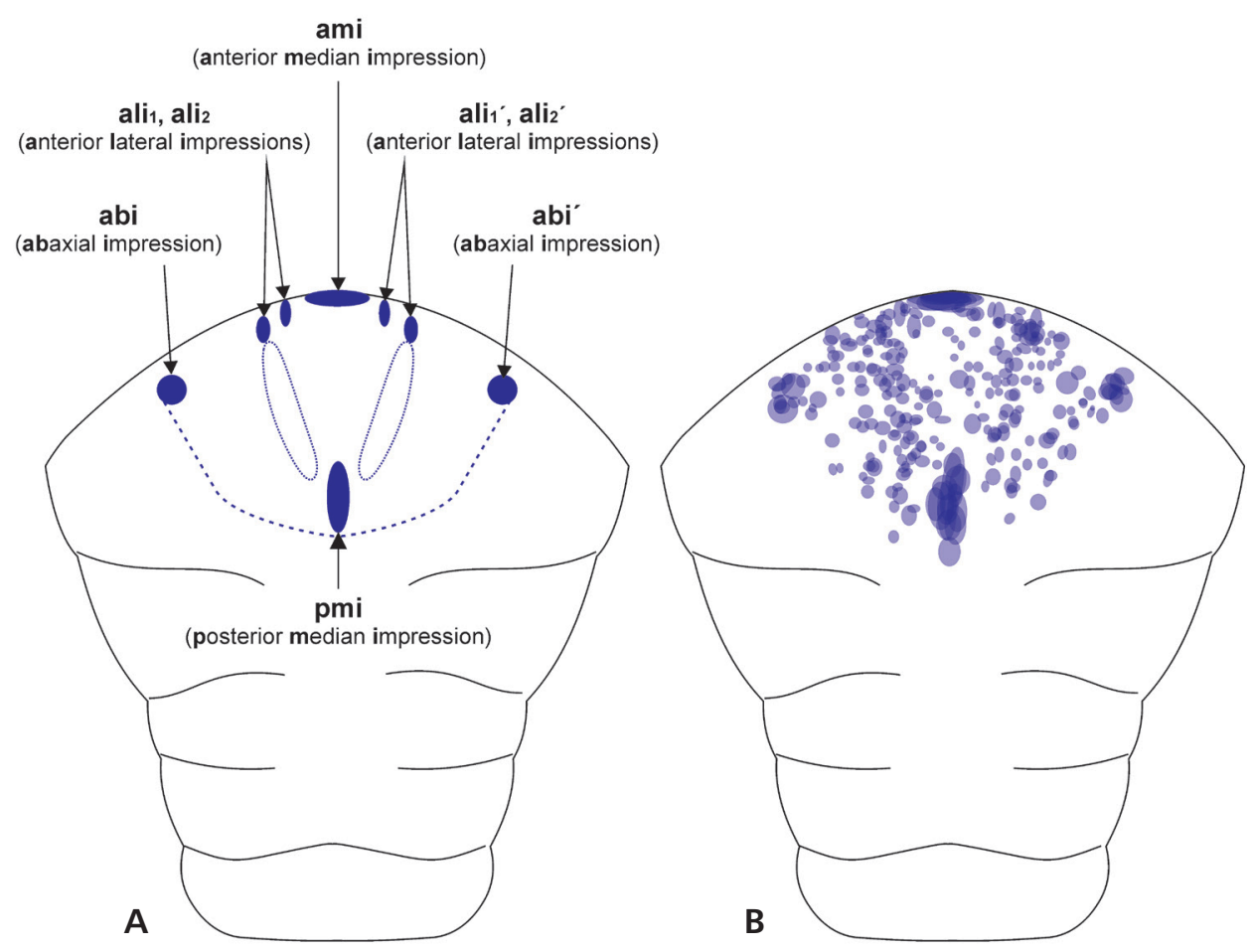


Frontal auxiliary impressions in Dalmanitina socialis were only observed on internal moulds, being expressions of pads (positive reliefs) on the visceral surface of the glabella. No evidence of the presence of FAIs was found on the external surface of the glabella in this species, despite the study of $c a 600$ cephala.

\section{Description}

Morphological terminology used follows that of Whittington \& Kelly (1997). Abbreviations of repositories: NM L - National Museum, Prague; ČGS - Czech Geological Survey, Prague; MFN T - Museum für Naturkunde, Berlin.

$\check{C} G S M \check{S} 7212$ (Figs $3 A, A_{1} ; 6 A$ ). - About thirty-five more or less symmetrically disposed, small FAIs are preserved on the frontal glabellar lobe (Fig. 6A). A pmi is developed as a sagittally elongate pad, composed of a deeper posterior part and a rounded and shallower anterior part (see Fig. 3A). Five other impressions are conspicuous; a large, elliptical medial imprint (ami; Fig. $3 \mathrm{~A}_{1}$ ) is associated with two other deep, more lateral pits $\left(\mathrm{ali}_{2}\right.$, ali ${ }_{2}$; Fig. $\left.3 \mathrm{~A}_{1}\right)$, all situated near the anterior glabellar margin. Two other rounded imprints lie more posterolaterally (abi, abi'; Fig. $3 \mathrm{~A}_{1}$ ). About fifteen fine, rounded to slightly elliptical imprints are arranged along two rows connecting $\mathrm{abi}_{2}$ and $\mathrm{abi}_{2}{ }^{\prime}$ with the very distinct pmi.

$\check{C} G S M \check{S} 7237$ (Figs 3B, $B_{1} ; 6 B$ ). - A distinct pmi is developed as a deep, sagittally elongate pad (see Fig. 3B). A set of about thirty symmetrically disposed FAIs is seen on the anterior glabellar lobe. Seven FAIs are conspicuous; five of these pits occur at the anterior margin of the glabella, where a deep triangular ami is bounded by two sagittally elongate imprints on the left side $\left(\mathrm{ali}_{1}\right.$ and $\mathrm{ali}_{2}$ in Fig. $\left.3 \mathrm{~A}_{1}\right)$ and by two rounded imprints on the right side $\left(\mathrm{ali}_{1}{ }^{\prime}\right.$ and $\mathrm{ali}_{2}{ }^{\prime} ;$ Fig. $\left.3 \mathrm{~A}_{1}\right)$. Two rounded pits are seen in a more posterolateral position (abi and abi'; Fig. $3 \mathrm{~B}_{1}$ ). Also, about ten fine imprints are arranged along two rows connecting $\mathrm{ali}_{1}$ and $\mathrm{ali}_{2}{ }^{\prime}$ with the pmi.

$\check{C} G S M \check{S} 7255$ (Figs $3 C, C_{1}$; 6C). - A set of about twenty evenly spaced FAIs is preserved on the anterior glabellar lobe, of which the pmi and ami are the most distinct. Five of the FAIs are conspicuous; an elliptical medial anterior imprint is surrounded by two deep anterior imprints $\left(\mathrm{ali}_{1}\right.$ and $\mathrm{ali}_{1}{ }^{\prime}$; Fig. $3 \mathrm{C}_{1}$ ), and two rounded and banana-shaped imprints are seen more posterolaterally (abi and abi'; Fig. 3C). About ten fine imprints are arranged along rows connecting a distinct posterior median impression with the anterior glabellar margin.
$\check{C} G S M \check{S} 7229$ (Figs 3D, $D_{1} ; 6 D$ ). - About twenty fine and shallow FAIs are preserved. Only four very weak impressions are visible on the left side of the glabella; about fifteen impressions are developed on the right side, the most prominent in the right lateral sector. A distinct, ellipsoidal pmi is composed of two rounded pads. There is a well-developed, elliptical ami associated with $\mathrm{ali}_{1}, \mathrm{ali}_{1}{ }^{\prime}$ and $\mathrm{ali}_{2}{ }^{\prime}$; both abi and abi' are also present (Fig. $3 \mathrm{D}_{1}$ ).

$\check{C} G S M \check{S} 7253$ (Figs 4A, $A_{1}$; 6E). - A distinct, ellipsoidal pmi is composed of two rounded pads. There is a weakly developed, elliptical ami. About thirty shallow FAIs are preserved, those on the left side arranged in a row connecting the anterior glabellar margin with the pmi (Figs 4A, 6E). Two pairs of anterior impressions are deep and slightly elliptical (Fig. 4A $\mathrm{A}_{1}$ ). Posterolateral impressions are present but weakly developed.

$\check{C} G S M \check{S} 7244$ (Figs 4B, $B_{1} ; 6 F$ ). - Small, slightly elliptical, deep pmi; ami small and shallow, both pairs of anterior impressions well developed and elliptical in outline $\left(\mathrm{ali}_{1}, \mathrm{ali}_{1}{ }^{\prime}\right.$ and $\mathrm{ali}_{2}, \mathrm{ali}_{2}{ }^{\prime}$; Fig. $\left.4 \mathrm{~B}_{1}\right)$. Posterolateral impressions very weakly developed (see Fig. $4 \mathrm{~B}_{1}$ ). Only four small FAIs are preserved on the surface of the porous internal mould of the frontal glabellar lobe (Fig. 6F).

$\check{C} G S X A 23 b$ (Figs 4C, $C_{1}$; 6G). - Small, deep pmi, subrounded in outline. Three anterior impressions are indistinctly developed ( $\mathrm{ali}_{1}{ }^{\prime}$, ali ${ }_{2}$ and $\mathrm{ali}_{2}{ }^{\prime}$; Fig. $4 \mathrm{C}_{1}$ ). Posterolateral impressions are developed as shallow, smooth surfaces. About ten small, shallow FAIs are irregularly dispersed on the frontal glabellar lobe (Fig. 6G).

CGS XA 23 a (Figs $4 D, D_{1} ; 6 H$ ). - The pmi is rounded and deep; ami, ali ${ }_{1}, \mathrm{ali}_{1}{ }^{\prime}$ and both $\mathrm{abi}_{1}, \mathrm{abi}_{1}{ }^{\prime}$ are poorly developed; $\mathrm{ali}_{2}$ and $\mathrm{ali}_{2}{ }^{\prime}$ relatively deep and distinct (Figs. $4 \mathrm{D}, \mathrm{D}_{1}$ ). About thirty small and shallow FAIs are irregularly distributed (Fig. 6H).

MFN T1638.3 (Figs 5A, $A_{1}$; 6I). - Deep pmi, elliptical in outline; ami is narrow; $\mathrm{ali}_{1}, \mathrm{ali}_{1}{ }^{\prime}, \mathrm{ali}_{2}{ }^{\prime}$ and both $\mathrm{abi}_{1}$, $\mathrm{abi}_{1}{ }^{\prime}$ are well developed; $\mathrm{ali}_{2}$ is not preserved (Figs 5A, $A_{1}$ ). Seven small FAIs are preserved on the left side of the glabella (Fig. 6I).

MFN T1638.1 (Figs 5B, $B_{1}$; 6J). - Relatively shallow pmi is composed of two rounded imprints. All other FAIs are well preserved, including about twelve small imprints, all arranged in two longitudinal rows on the anteriormost glabellar lobe (Fig. 6J).

NM L 59867 (Figs 5C, 6K). - The pmi is rounded. Small ami associated with poorly preserved $\mathrm{ali}_{2}$ and $\mathrm{ali}_{2}{ }^{\prime}$. 

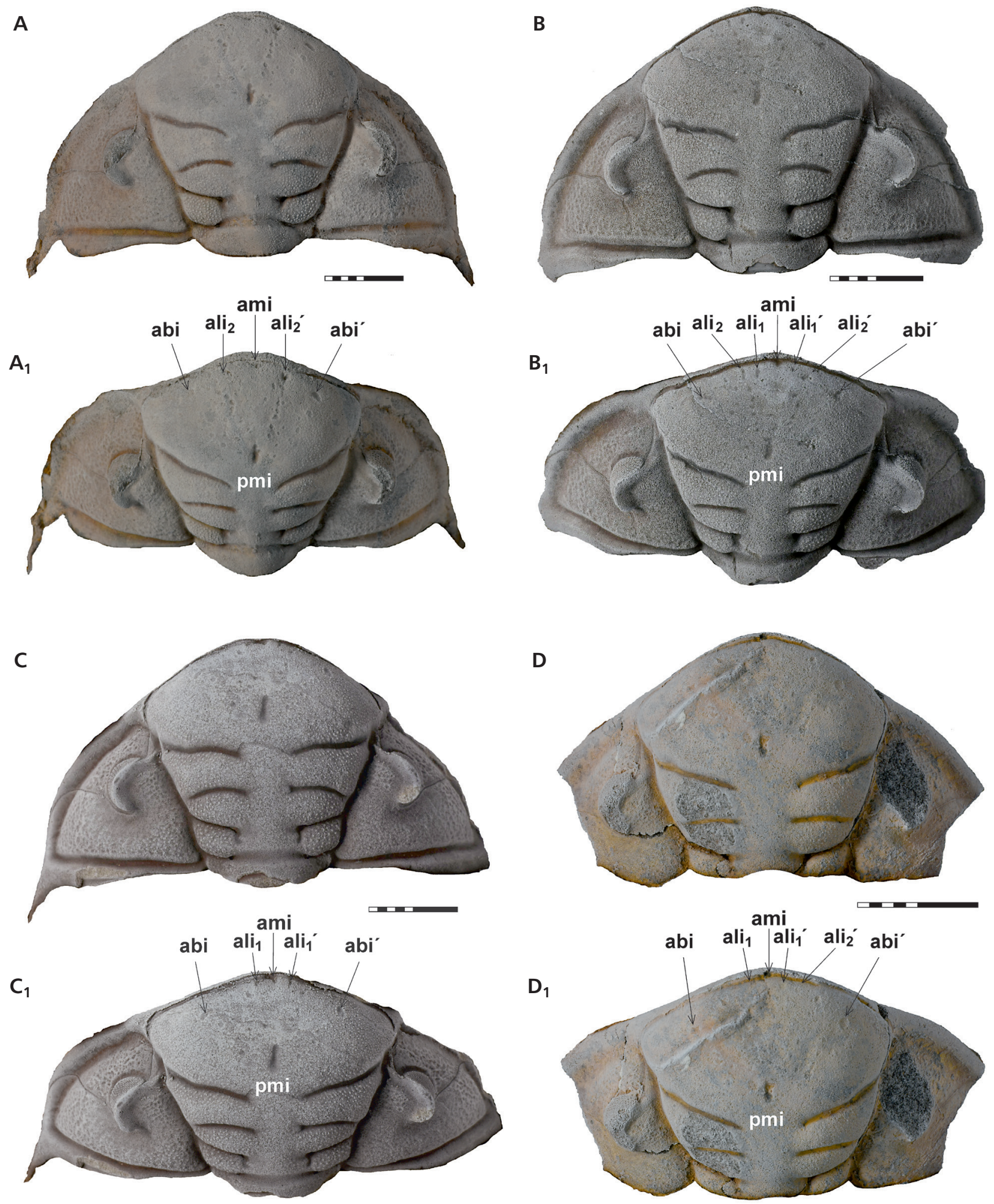

Figure 3. Internal moulds of cephala of Dalmanitina socialis (Barrande, 1846) with FAIs, Upper Ordovician Letná Formation, Berounian Regional Stage (Sandbian to lower to middle Katian), Prague Basin. A, $A_{1}$ - well-vaulted internal mould of cephalon with both genal spines, showing slightly damaged eyes, Děd Hill near Beroun, ČGS MŠ 7212; B, $B_{1}$ - strongly vaulted internal mould of cephalon with both genal spines missing and with well-preserved eyes, Veselá Hill, Beroun, ČGS MŠ 7237; C, $\mathrm{C}_{1}$ - three-dimensional cephalon with left genal spine in situ and with excellently preserved eyes, Beroun - Veselá Hill, ČGS MŠ 7255; D, D - incomplete vaulted cranidium with partially preserved genae and left eye, right eye and occipital ring missing, Beroun - Ostrý Hill, ČGS MŠ 7229. 

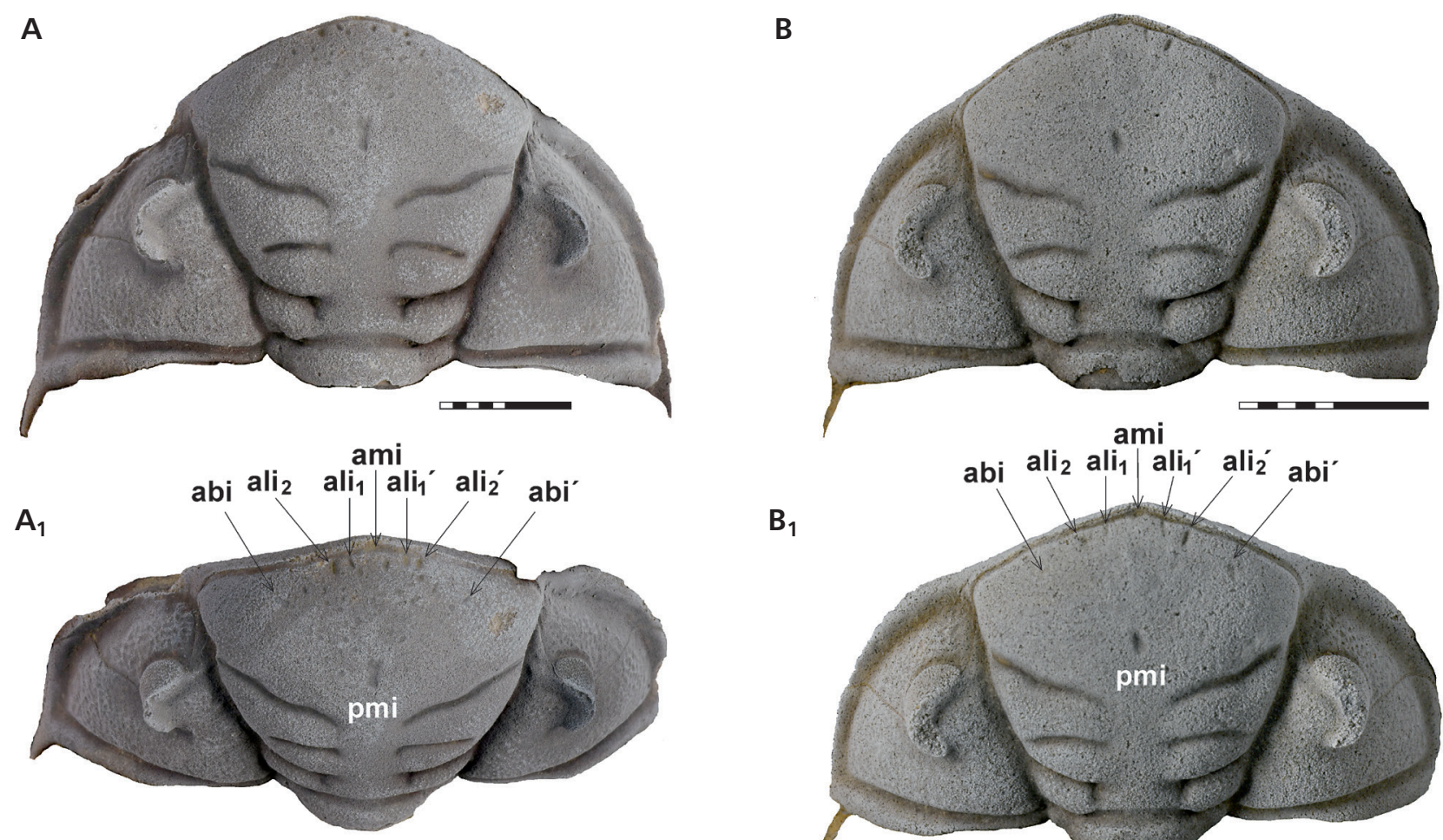

$\mathrm{B}_{1}$
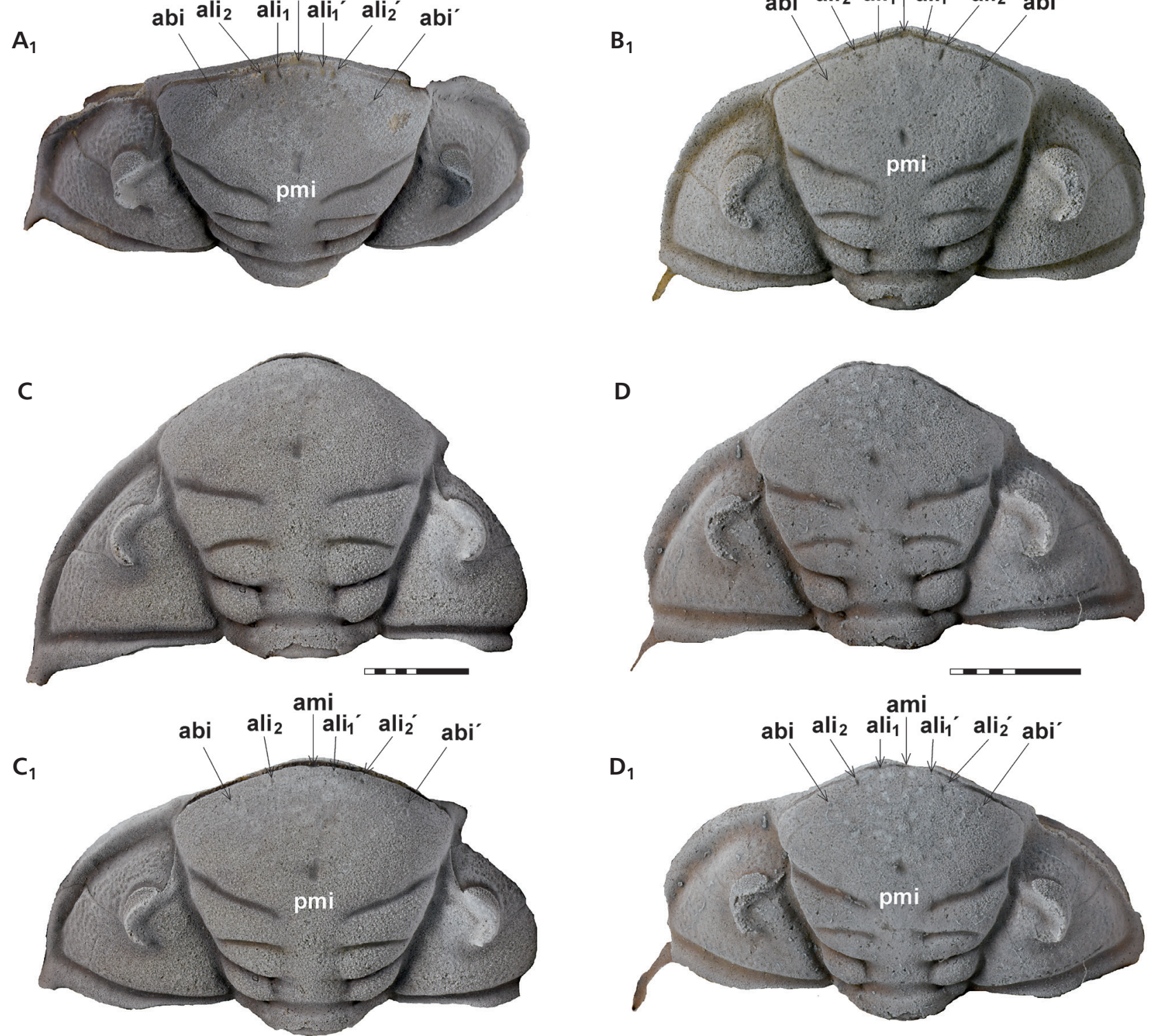

Figure 4. Internal moulds of cephala of Dalmanitina socialis (Barrande, 1846) with FAIs, Upper Ordovician Letná Formation, Berounian Regional Stage (Sandbian to lower to middle Katian), Prague Basin. A, $A_{1}$ - complete vaulted cephalon with both eyes and both genal spines, Veselá Hill, Beroun, ČGS MŠ 7253; B, B 1 - complete well-vaulted cephalon with the left genal spine and slightly damaged eyes, Veselá Hill, Beroun, ČGS MŠ 7244; C, $C_{1}$ - incomplete highly vaulted cranidium with both eyes and partially damaged right anterolateral cephalic margin, Veselá Hill, Beroun, C̆GS XA 23b; D, D - nearly complete vaulted cephalon with both eyes and left genal spine, Veselá Hill, Beroun, ČGS XA 23 a. 
A
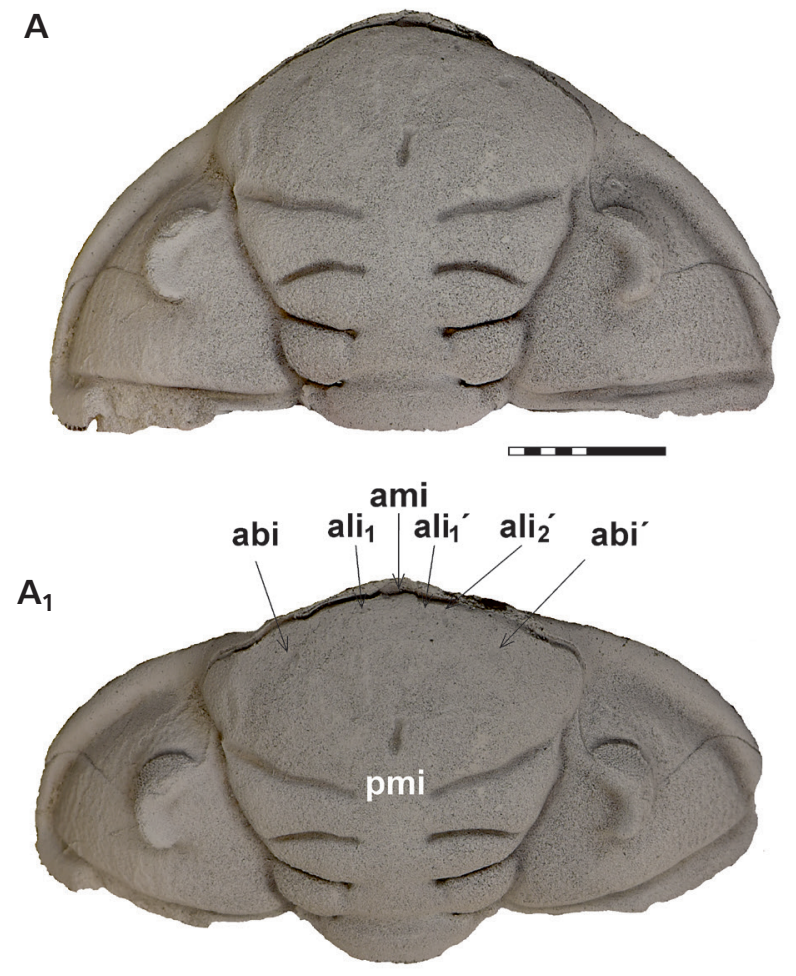

C

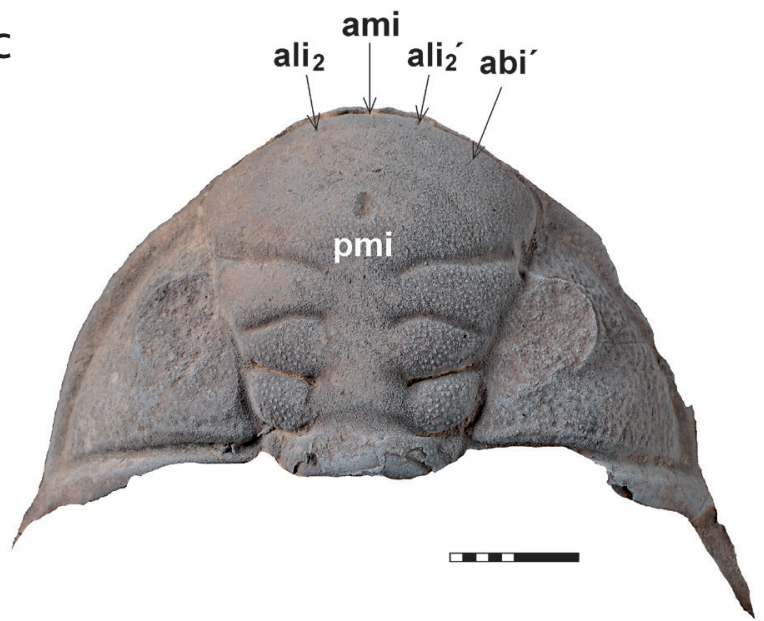

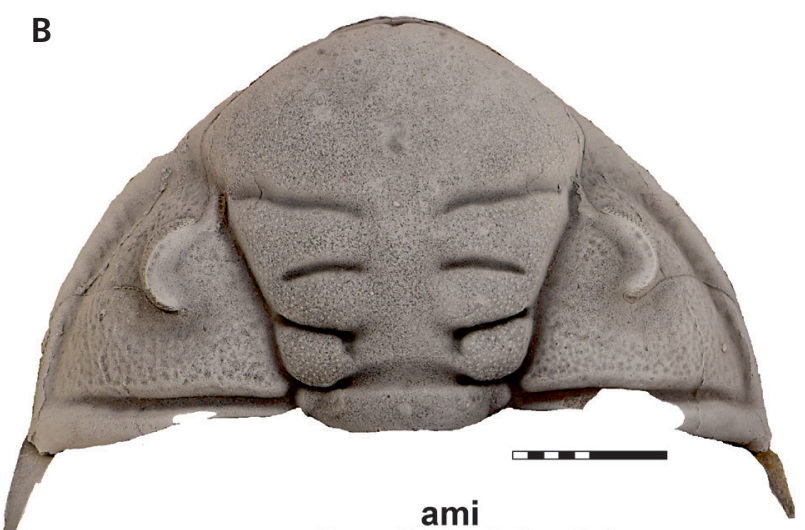

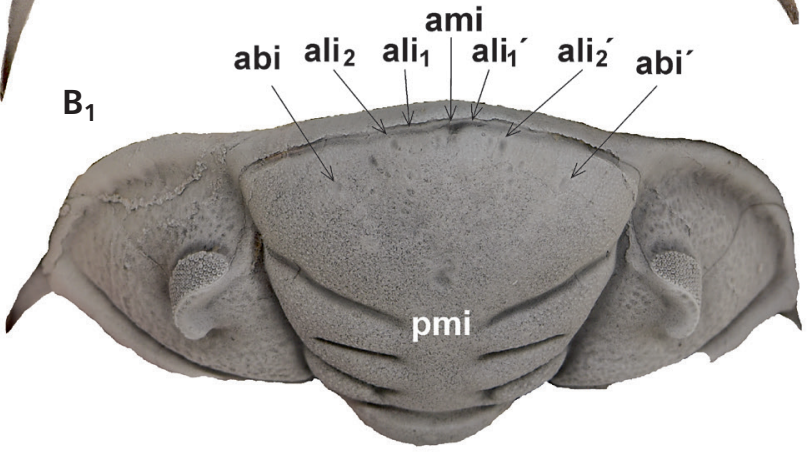

D abi $\operatorname{ali}_{2} \stackrel{\text { ami }}{a}$ alí $_{2} \mathrm{abi}^{\prime}$

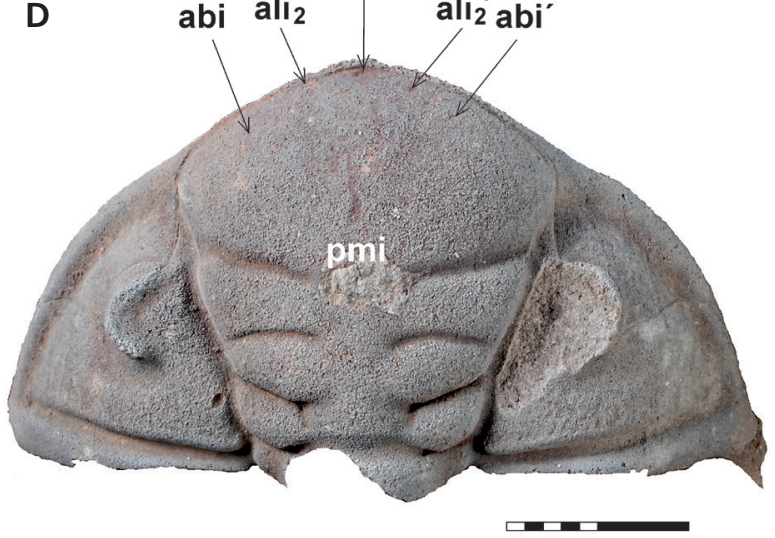

Figure 5. Internal moulds of cephala of Dalmanitina socialis (Barrande, 1846) with FAIs, Upper Ordovician Letná Formation, Berounian Regional Stage (Sandbian to lower to middle Katian), Prague Basin. A, $A_{1}$ - incomplete vaulted cephalon with both eyes and lacking both genal spines, Děd Hill, Beroun, MFN T1638.3; B, B 1 - strongly vaulted cephalon with both genal spines and excellently preserved eyes, Děd Hill, Beroun, MFN T1638.1; C - vaulted, slightly damaged cephalon with complete right and incomplete left genal spines and with both eyes missing, Děd Hill, Beroun, NM L 59867; D - nearly complete vaulted cephalon lacking right eye and with damaged occipital ring, Děd Hill, Beroun, NM L 59868.

The right abi' is poorly developed. About five small FAIs are present in the anteriormost part of the glabella (Fig 6K).

NML 59868 (Figs 5D, 6L). - The pmi and ami are shallow; $\mathrm{ali}_{1}$ and $\mathrm{ali}_{1}{ }^{\prime}$ not preserved; $\mathrm{ali}_{2}$, $\mathrm{ali}_{2}{ }^{\prime}$ and both lateral impressions (abi and abi'; Fig. 5D) are shallow and rounded. Other FAIs are tiny and very poorly visible (Fig. $6 \mathrm{~L}$ ).

\section{Discussion}

\section{Frontal auxiliary impressions (FAls)}

Frontal auxiliary impressions are usually interpreted as attachment sites for strong extrinsic muscles enabling suspension and dilatation of the anterior part of the 

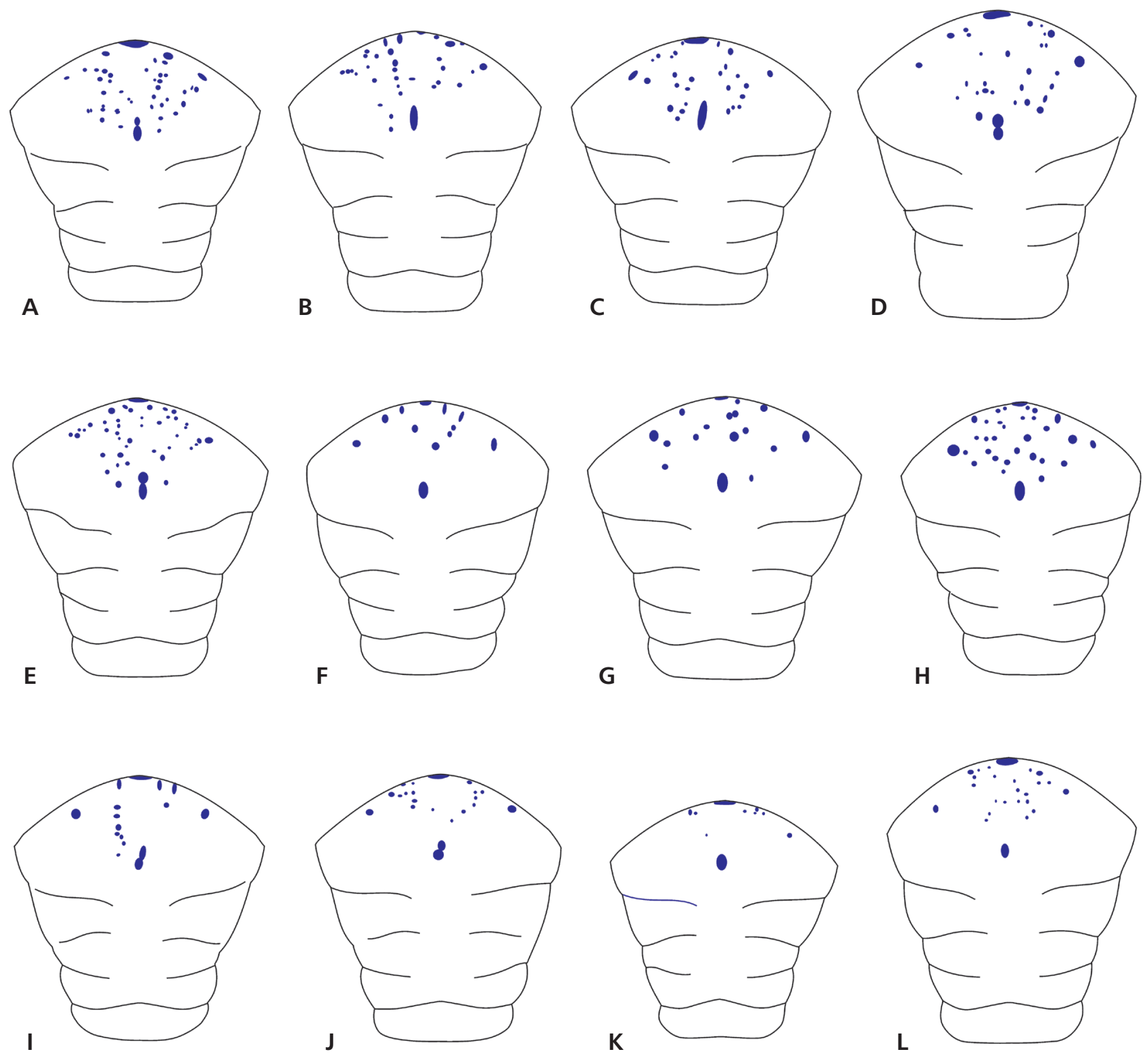

Figure 6. Interpretative sketches of the specimens of Dalmanitina socialis (Barrande, 1846) studied herein with the distribution of FAIs. A - $\breve{C} G S$ MS 7212 (Fig. 3A); B - ČGS MŠ 7237 (Fig. 3B); C - ČGS MŠ 7255 (Fig. 3C); D - ČGS MŠ 7229 (Fig. 3D); E - ČGS MŠ 7253 (Fig. 4A); F - ČGS MŠ 7244 (Fig. 4B); G - C̆GS XA 23b (Fig. 4C); H - ČGS XA 23a (Fig. 4D); I - MFN T1638.3 (Fig. 5A); J - MFN T1638.1 (Fig. 5B); K - NM L 59867 (Fig. 5C); L-NM L 59868 (Fig. 5D).

digestive system (for detail discussion see LeroseyAubril et al. 2011, pp. 172-178). FAIs are regarded as indicative of a major modification of the foregut: its differentiation into a well-developed pouch-like organ (i.e. a crop) comparable to the stomach of modern spiders or the proventriculus of crabs, the function of which (e.g. pumping, chewing/filtering) required a powerful musculature (see Dunlop et al. 1992, Marples 1983, Lerosey-Aubril et al. 2011).

\section{Frontal auxiliary impressions in Dalmanitina}

In Dalmanitina, the preservation of FAIs is exceedingly rare, but a given specimen may exhibit several tens of them, typically subcircular and faint. Of the $c a 600$ cephala of this taxon investigated in the course of this study, FAIs were found in twelve specimens only; these structures are preserved exclusively on internal or composite moulds (see Figs 3-5). The FAIs of Dalmanitina are arranged in 
a characteristic triangle, which reaches its maximal width along the anterior margin of the frontal glabellar lobe.

In some specimens, FAIs are disposed in two very slightly diverging rows (Fig. 6A, B, I, J) associated with a wide row of usually larger, elliptical or irregularly shaped and deeper impressions along the anterior glabellar margin. Such a configuration agrees well with the dalmanitid distribution pattern of FAIs (sensu Eldredge 1971, 1979). The distribution pattern of FAIs was used as diagnostic for the higher systematics of Phacopina by Eldredge (1971, 1979), Edgecombe (1993, 1994) and Carvalho et al. (2003). However, it is noteworthy that the FAIs in Dalmanitina seem to show variability in both shape and outline (Fig. 2A), and this does not seem to be solely explained by taphonomy. FAIs in some specimens do not form a triangular configuration but a rather irregular cluster of impressions that occupies a large part of the anterior half of the anterior glabellar lobe (Fig. 6D, E, H, L). Such distribution pattern of FAIs may indicate some limited taxonomic importance for FAIs in Ordovician dalmanitids. It is also necessary to point out that, although the faint FAIs are rarely preserved, at least one or more of the more conspicuous FAIs (ali, abi, pmi) have been observed in numerous specimens of Dalmanitina examined during this study. These more conspicuous marks form a polygonal field in which faint FAIs are irregularly scattered. A comparable arrangement of deep and shallow FAIs in a slightly modified form was discussed by Šnajdr (1987) and Budil et al. (2008, 2009) in Odontochile and Zlichovaspis (see also Richter 1923). At the anteriormedial tip of the glabella, a large impression (ami) was observed in about $70 \%$ of specimens of Dalmanitina. This large impression also belongs, most probably, to the same system (see also Barrande 1852,1872 ). The posterior median impression (pmi) is characteristic of many other dalmanitids; e.g. Chattiaspis, Crozonaspis, Dalmanites, Daytonia, Eodalmanitina, Francovichia, Guichenia, Morgatia, and Zeliszkella (see Henry 1965, 1968, 1980, 1989; Nion \& Henry 1966; Henry \& Morzadec 1968; Wolfart 1968; Henry et al. 1974; Eldredge 1971; Robardet et al. 1972; Hammann 1972, 1974; Chatterton \& Ludvigsen 2004; see also LeroseyAubril \& Peel, 2018 and Gutiérrez-Marco et al. 2019).

In two articulated specimens of Dalmanitina [Fatka, unpublished data, specimens NM L 51954 (National Museum, Prague) and MB 1965.2.13 (Museum für Naturkunde, Berlin)], the anteriormost portion of the glabella collapsed while the hypostome was still in situ. This collapsed cavity clearly represents the space enclosed between the hypostome and dorsal exoskeleton rather than the remains of the crop (see Fatka et al. 2013 and LeroseyAubril \& Peel 2018, p. 752, for similar interpretations). This is confirmed by the absence of a connection between this cavity and the remains of the digestive tract visible under the trunk axis as well as in the posterior portion of the glabella. In support of this, Fatka (unpublished data) concluded that in Dalmanitina, the crop occupied only the posterior portion of the frontal glabellar lobe (see Lerosey-Aubril \& Peel 2018 and Wendruff et al. 2020).

The presence of characteristic FAIs in some specimens of Dalmanitina clearly indicates the existence of strong extrinsic muscles connecting the foregut to the dorsal exoskeleton. Such morphology suggests possible differentiation of a well-developed crop. Both the presence of a crop in Dalmanitina and the fact that it did not occupy the whole cavity underneath the frontal glabellar lobe finds support in the recent illustration of specimens of an undescribed Silurian dalmanitid from the Waukesha Lagerstätte showing digestive structures, including a crop and paired digestive glands (Wendruff et al. 2020, figs 3d, f).

\section{Conclusions}

Study of twelve excellently preserved cephalic shields of Dalmanitina allows the recognition of prominent FAIs in this taxon (pmi, ami, ali and abi) circumscribing an area bearing much fainter FAIs. FAIs in this taxon were only present on the visceral surface of the dorsal exoskeleton (glabellar frontal lobe). The configuration of FAIs in Dalmanitina may vary from somewhat regular and triangular to irregular and somewhat oval in outline, questioning the use of the distribution patterns of FAIs for taxonomic purposes. This supports the claim of LeroseyAubril \& Peel (2018, p. 751) that the distribution pattern of FAIs might be of limited use for study of phylogenetic relationships between major trilobite groups.

\section{Acknowledgements}

We thank Rudy Lerosey-Aubril (Harvard University, Cambridge, MA, USA) and Derek Siveter (University of Oxford, UK) for their helpful review and the linguistic improvements that were made on our text. David Holloway (Museums Victoria, Melbourne, Australia) for constructive comments on an earlier version of this contribution. Lukáš Laibl (Charles University, Prague, Czech Republic) is acknowledged for sharing knowledge on several specimens of Dalmanitina with FAIs. This research was supported by the Grant Agency of the Czech Republic (GACR), project no. 18-14575S, and by PROGRES Q45 of the Ministry of Education, Youth and Sports of the Czech Republic (OF). This is a contribution to IGCP 668, Equatorial Gondwanan History and Early Palaeozoic Evolutionary Dynamics.

\section{References}

BarRANDE, J. 1846. Notice préliminaire sur le Systême silurien et les trilobites de Bohême. 97 pp. Hirschfeld, Leipzig. 
Barrande, J. 1852. Systême silurien du centre de la Bohême. lère partie: Recherches paléontologiques. Vol. 1. Crustacés: Trilobites. 935 pp. Privately published, Prague \& Paris. DOI 10.5962/bhl.title.14776

Barrande, J. 1872. Systême silurien du centre de la Bohême. lère partie: Recherches paléontologiques. Supplément au Vol. I. Trilobites, crustacés divers et poissons. 647 pp. Privately published, Prague \& Paris.

Bergström, S.M., Chen, X., Gutiérrez-Marco, J.C. \& Dronov, A. 2009. The new chronostratigraphic classification of the Ordovician System and its relations to major regional series and stages and to $\delta^{13} \mathrm{C}$ chemostratigraphy. Lethaia $42(1)$, 97-107. DOI 10.1111/j.1502-3931.2008.00136.x

Born, A. 1919. Zur Organisation der Trilobiten. I. Das Kopfschild von Chasmops odini Eichw. Senckenbergiana 1(5), 159-171.

Budil, P. \& FATKA, O. 2020. Ordovician trilobites with soft-parts in West Gondwana and European peri-Gondwana: a review. Geological Society of London, Special Publication 485. DOI 10.1144/SP485-2019-152

Budil, P., FatKa, O., Kolář, P. \& David, M. 2011. Arthrorhachis Hawle \& Corda, 1847 (Agnostida) in the Prague Basin (Barrandian area, Czech Republic) revisited. Bulletin of Geosciences 85(4), 707-724. DOI 10.3140/bull.geosci.1262

Budil, P., Hörbinger, F. \& Mencl, R. 2009. Lower Devonian dalmanitid trilobites of the Prague Basin (Czech Republic). Earth and Environmental Science Transactions of the Royal Society of Edinburgh 99(2), 61-100. DOI $10.1017 / \mathrm{S} 1755691009006161$

Budil, P., Thomas, A.T. \& Hörbinger, F. 2008. Exoskeletal architecture, hypostomal morphology and mode of life of Silurian and Lower Devonian dalmanitid trilobites. Bulletin of Geosciences 83(1), 1-10.

DOI 10.3140/bull.geosci.2008.01.001

Carvalho, M.G.P., Edgecombe, G.D. \& Smith, L. 2003. New calmoniid Trilobites (Phacopina: Acastoidea) from the Devonian of Bolivia. American Museum Novitates 3407, 1-17. DOI 10.1206/0003-0082(2003)407<0001:NCTPAF >2.0.CO;2

Chatterton, B.D.E. \& Ludvigsen, R. 2004. Early Silurian of Anticosti Island, Québec, Canada. Palaeontographica Canadiana 22, 1-264.

Chlupáč, I. 1988. The enigmatic arthropod Duslia from the Ordovician of Czechoslovakia. Palaeontology 31(3), 611-620.

CHLupáč, I. 1999a. Some problematical arthropods from the Upper Ordovician Letná Formation of Bohemia. Journal of the Czech Geological Society 44(1-2), 79-87.

CHLuṕ́, I. 1999b. Unusual arthropods from the Bohemian Ordovician - a review. Acta Universitatis Carolinae, Geologica 43(1-2), 393-396.

Drage, H.B., Laibl, L. \& Budil, P. 2018. Postembryonic development of Dalmanitina, and the evolution of facial suture fusion in Phacopina. Paleobiology 44(4), 638-659. DOI 10.1017/pab.2018.31

Dunlop, J.A., Altringham, J.D. \& Mill, P. 1992. Coupling between the heart and sucking stomach during ingestion in a tarantula. Journal of Experimental Biology 166, 83-93.
Edgecombe, G.D. 1993. Silurian acastacean trilobites of the Americas. Journal of Paleontology 67(4), 535-548.

DOI 10.1017/S0022336000024884

Edgecombe, G.D. 1994. Calmoniid trilobites from the Devonian Fox Bay Formation, Falkland Islands: systematics and biogeography. Bulletin of the New York State Museum and Science Service 481, 55-68.

Edgecombe, G.D. \& Fortey, R.A. 2000. Silurian trilobites from the El Carmen Formation, Bolivia. Senckenbergiana lethaea 79(2), 329-355.

Eldredge, N. 1971. Patterns of cephalic musculature in the Phacopina (Trilobita) and their phylogenetic significance. Journal of Paleontology 45(1), 52-67.

Eldredge, N. 1972. Morphology and relationships of Bouleia Kozłowski, 1923 (Trilobita, Calmoniidae). Journal of Paleontology 46(1), 140-151.

Eldredge, N. 1979. Cladism and common sense, 165-198. In Cracraft, J. \& Eldredge, N. (eds) Phylogenetic analysis and paleontology. Columbia University Press, New York. DOI 10.7312/crac92306-007

Eldredge, N. \& Braniša, L. 1980. Calmonid trilobites of the Lower Devonian Scaphiocoelia zone of Bolivia, with remarks on related species. Bulletin of the American Museum of Natural History 165(2), 181-289.

EMmrich, H.F. 1839. De Trilobitis: Dissertatio petrefactologica quam consensu \& auctoritate amplissimi philosophorum ordinis in Alma litterarum Universitate Frederica Guildma pro summis in philosophia honoribus. 56 pp. Nietack, Berlin.

Fatka, O., Lerosey-Aubril, R., Budil, P. \& RaK, Š. 2013. New examples of fossilised guts in trilobites from the Upper Ordovician Letná Formation (Prague Basin, Czech Republic). Bulletin of Geosciences 88(1), 95-104.

DOI 10.3140/bull.geosci.1329

Gutiérrez-Marco, J.C., Pereira, S., García-Bellido, D.C. \& RÁBANO, I. 2019. Ordovician trilobites from the Tafilalt Lagerstätte: new data and reappraisal of the Bou Nemrou assemblage. Geological Society of London, Special Publiations 485. DOI 10.1144/SP485-2018-126

Hammann, W. 1972. Neue propare Trilobiten aus dem Ordovizium Spaniens. Senckenbergiana lethaea 53(5), 371-381.

Hammann, W. 1974. Phacopina und Cheirurina (Trilobita) aus dem Ordovizium von Spanien. Senckenbergiana lethaea 55(1-5), 1-151.

Harrington, H.J. 1959. General description of Trilobita, 38-117. In Moore, R.C. (ed.) Treatise on invertebrate paleontology. Part O. Arthropoda 1. Geological Society of America \& University of Kansas Press, Boulder, Colorado \& Lawrence, Kansas.

HavlíčEK, V. \& Marek, L. 1973. Bohemian Ordovician and its international correlation. Časopis pro Mineralogii a Geologii 18(3), 225-232.

HAVLÍČEK, V. \& VANĚK, J. 1966. The biostratigraphy of the Ordovician of Bohemia. Sborník geologických věd, Paleontologie 8, 7-69.

HAVlíČEK, V. \& VANĚK, J. 1990. Ordovician invertebrate communities in black-shale lithofacies (Prague Basin, Czecho- 
slovakia). Věstník Ústředního ústavu geologického 65(4), 223-236.

Henry, J.-L. 1965. Révision de deux Zeliszkellinae (trilobites) des 'schistes à Calymènes' (Llandeilien) du Massif Armoricain. Bulletin de la Société Géologique de France (Series 7) 6, 139-145.

Henry, J.-L. 1968. Crozonaspis struvei n.g. n.sp., Zeliszkellinae (Trilobita) de 1'Ordovicien moyen de Bretagne. Senckenbergiana Lethaea 49(5-6), 367-381.

Henry, J.-L. 1980. Trilobites ordoviciens du Massif Armoricain. Mémoires de la Société Géologique et Minéralogique de Bretagne 22, 1-250.

Henry, J.-L. 1989. Paléoenvironnements et dynamique de faunes de trilobites dans 1'Ordovicien (Llanvirn supérieur-Caradoc basal) du Massif Armoricain (France). Palaeogeography, Palaeoclimatology, Palaeoecology 73(1-2), 139-153.

Henry, J.-L. \& Morzadec, P. 1968. Sur la présence du sousgenre Phacopidella (Prephacopidella) Destombes, 1963 (trilobite) dans les schistes ordoviciens du Portugual. Compte Rendu Sommaire des Séances de la Société Géologique de France 5, 158-159.

Henry, J.-L., Nion, J., Paris, F. \& Thadeu, D. 1974. Chitinozoaires, ostracodes et trilobites de l'Ordovicien du Portugal (serra de Buçaco) et du massif Armoricain: essai de comparaison et signification paléogéographique. Comunicações dos Serviços Geológicos de Portugal 57, 303-345.

JAHN, J.J. 1893. Duslia, eine neue Chitonidegattung aus dem böhmischen Untersilur, nebst einigen Bemerkungen über die Gattung Triopus Barr. Sitzungsberichte der Kaiserlichen Akademie der Wissenschaften 102, 591-603.

Lerosey-Aubril, R., Hegna, T.A. \& Olive, S. 2011. Inferring internal anatomy from the trilobite exoskeleton: the relationship between frontal auxiliary impressions and the digestive system. Lethaia 44(2), 166-184.

DOI 0.1111/j.1502-3931.2010.00233.x

Lerosey-Aubril, R. \& Peel, J.S. 2018. Gut evolution in early Cambrian trilobites and the origin of predation on infaunal macroinvertebrates: evidence from muscle scars in Mesolenellus. Palaeontology 61(5), 747-760.

DOI 10.1111/pala.12365

MARPLES, B.J. 1983. Observations on the structure of the foregut of spiders. Bulletin of the British Arachnological Society 6(1), 46-52.

Nion, J. \& Henry, J.-L. 1966. Phacopidella (Prephacopidella) hupei nov. sp., nouveau trilobite de l'Ordovicien du Finistère. Bulletin de la Société Géologique de France (Series 7) 8, 884-890.

Rak, Š., Ortega-Hernández, J. \& LegG, D.A. 2013. A revision of the Late Ordovician marrellomorph arthropod Furca bohemica from Czech Republic. Acta Palaeontologica Polonica 58(3), 615-628. DOI 10.4202/app.2011.0038
RAmSKöLd, L. \& Edgecombe, G.D.E. 1993. Silurian (Ludlow) acastid trilobites from Gotland and Scania, Sweden. Paläontologische Zeitschrift 67(3), 261-285.

DOI 10.1007/BF02990280

ReEd, F.R.C. 1905. The classification of the Phacopidae. Geological Magazine 42, 172-178, 224-228.

DOI 10.1017/S0016756800131991

Robardet, M., Henry, J.-L., Nion, J., Paris, F. \& Pillet, J. 1972. La Formation du Pont-de-Caen (Caradocien) dans les synclinaux de Domfront et de Sées (Normandie). Annales de la Société Géologique du Nord 92, 117-137.

Richter, R. 1923. Von Bau und Leben der Trilobiten III. Die Beziehung von Glatze und Magen. IV. Die Versteifungen der Schale und daraus hervorgehende Konvergenzen. Palaeontologia Hungarica 1, 77-108.

ŠnAJDR, M. 1956. Trilobiti drabovských a letenských vrstev českého ordoviku (Trilobites from the Drabov and Letná beds of the Ordovician of Bohemia). Sbornik Ústředniho ústavu geologického, Oddil paleontologický 22 (1955), 477-533.

ŠNAJDR, M. 1982a. Bohemian representatives of the trilobite genera Kloucekia Delo, Phacopidina Bancroft, Sokhretia Hupé and Dalmanitina Reed. Věstník Ústředního ústavu geologického 57(3), 179-182.

ŠNAJDR, M. 1982b. New trilobites from the Bohdalec Formation (Berounian) in the Barrandian. Věstnik Ústředního ústavu geologického 57(4), 227-230.

ŠnAJDR, M. 1987. New Bohemian Ordovician Dalmanitidae and Calmonidae (Trilobita). Věstník Ústředního ústavu geologického 62(5), 271-277.

ŠNAJDR, M. 1990. Bohemian trilobites. 265 pp. Czech Geological Survey, Prague.

VANĚK, J. \& VoKÁČ V. 1997. Trilobites of the Bohdalec Formation (Upper Berounian, Ordovician, Prague Basin, Czech Republic). Palaeontologia Bohemiae 3, 20-50.

Wendruff, A.J., Babcock, L.E., Kluessendorf, J. \& Mikulic, D.G. 2020. Paleobiology and taphonomy of exceptionally preserved organisms from the Waukesha Biota (Silurian), Wisconsin, USA. Palaeogeography, Palaeoclimatology, Palaeocology 546, art. 109631.

DOI 10.1016/j.palaeo.2020.109631

Whittington, H.B. \& Kelly, S.R.A. 1997. Morphological terms applied to Trilobita, 313-329. In Kaesler, R.L. (ed.) Treatise on invertebrate paleontology, Part O, Arthropoda 1, Trilobita, revised, Volume 1: Introduction, Order Agnostida, Order Redlichiida. Geological Society of America \& University of Kansas Press, Boulder, Colorado \& Lawrence, Kansas.

Wolfart, R. 1968. Die Trilobiten aus dem Devon Boliviens und ihre Bedeutung für Stratigraphie und Tiergeographie. Beihefte zum Geologischen Jahrbuch 74, 5-201. 